\title{
Influence of coverage based on biopolymers on the maturation of cagaita (Eugenia dysenterica DC.)
}

\author{
Aline Jordane Braz ${ }^{1}$, Letícia de Paula Nascente ${ }^{1}$, Nayara Canedo Corrêa ${ }^{1}$, Rodrigo de \\ Almeida Rocha ${ }^{1}$, Eli Regina Barboza de Souza ${ }^{2}$, Ana Paula Silva Siqueira ${ }^{1}$ \\ ${ }^{1}$ Instituto Federal Goiano, Campus Urutaí, Urutaí, Goiás, Brasil. E-mail: alinejbraz@gmail.com, lethi.nascente@gmail.com, \\ nayaracorreadns@gmail.com, rodrigota99@outlook.com, ana.siqueira@ifgoiano.edu.br \\ ${ }^{2}$ Universidade Federal de Goiás, Campus Samambaia, Goiânia, Goiás, Brasil. E-mail: eliregina1 @ gmail.com
}

Received: 28/01/2019; Accepted: 18/10/2019.

\begin{abstract}
The cagaita is a native fruit of the cerrado, of high perishability, and for postharvest conservation of the fresh fruit, methods are used to increase its life cycle. In the present study, edible coatings are used, a technique that aims to control the loss of mass through transpiration reduces gas exchange, increases the shelf-life, improves the appearance, preserves the structural integrity and mechanical properties. The study aims to evaluate the influence of coatings based on biopolymers on the maturation of cagaita during storage. The factorial scheme $3 \times 4$ was used, with three treatments - without coating, polysaccharide coating and protein coating, four evaluation points - with an interval of 2 days, stored at $25^{\circ} \mathrm{C}$. The fruits were submitted to weight loss, $\mathrm{pH}$, titratable acidity, soluble solids, and ascorbic acid evaluations. There was no influence of the time factor in the present study, and for titratable acidity, ascorbic acid, soluble solids, and $\mathrm{pH}$, there was no significant difference between treatments. Observing the content of soluble solids, the main indicator of ripeness, which varies from 5 to $7^{\circ}$ Brix, it was concluded that the fruits did not ripen.
\end{abstract}

Keywords: Cerrado, edible coating, conservation, polysaccharides, protein.

\section{Influência de cobertura à base de biopolímeros na maturação da cagaita (Eugenia dysenterica $\mathrm{DC}$.)}

\section{RESUMO}

A cagaita é um fruto nativo do cerrado, de alta perecibilidade, e para conservação pós-colheita do fruto in natura são utilizados métodos para aumentar o seu ciclo de vida. No presente estudo são utilizadas as coberturas comestíveis, uma técnica que visa controlar a perda de massa pela transpiração, reduz as trocas gasosas, aumenta a vida útil, melhora a aparência, preserva a integridade estrutural e propriedades mecânicas. O objetivo foi avaliar a influência de coberturas à base de biopolímeros na maturação de cagaita ao longo do armazenamento. Utilizou-se o esquema fatorial $3 \times 4$, sendo 3 tratamentos - sem revestimento, revestimento de polissacarídeo e revestimento de proteína, 4 pontos de avaliação - com intervalo de 2 dias, armazenados a $25^{\circ} \mathrm{C}$. Os frutos foram submetidos a avaliações de perda de massa, pH, acidez titulável, teores de sólidos solúveis e ácido ascórbico. Não houve significância para o fator época no presente estudo, e para acidez titulável, ácido ascórbico, sólidos solúveis e pH não houve diferença estatística significativa entre os tratamentos. Observando-se o teor de sólidos solúveis, principal indicador de maturação, que varia de 5 a $7^{\circ} \mathrm{Brix}$, concluiu-se que os frutos não amadureceram.

Palavras-chave: Cerrado, cobertura comestível, conservação, polissacarídeos, proteína. 
Popularly known as cagaita, Eugenia dysenterica DC., from the Myrtaceae family, is a fruit native to the Cerrado. The plant has a production capacity that ranges between 500 and 2000 fruits, with the flowering period from August to October, and the life cycle of the fruits is about 40 days (Almeida Júnior et al., 2014; Silva and Tassara, 2003). The cagaita has a spherical shape, green when immature and yellow when ripe, with a weight of 14 to $20 \mathrm{~g}$ and a diameter between 3 and $5 \mathrm{~cm}$. Besides the specific flavor, slightly acidic, the fruit has a high content of vitamin C and A (Cardoso et al., 2011).

The cagaita, like most fruits, has a high degree of perishability due to the high metabolic activity after harvest, leading to the rapid deterioration of the fruit; the fruit has climacteric behavior, presenting a rapid and sharp increase in respiratory activity in one stage of its cycle. And, at this moment, the fast ripening of the fruits can happen in the plant or outside it, if harvested physiologically developed (Terán-Ortiz et al., 2013; Chitarra and Chitarra, 2005).

Due to the high productivity of the plant, the high perishability of the fruit, and because it is seasonal, it is necessary to apply post-harvest conservation methodologies. In the literature, several methodologies have been used to increase the useful life of fresh fruit, including refrigeration, packaging, and the use of biofilms and edible coatings. These fruits have also been destined for processing in the form of juice, liquor, jelly, and ice cream (Santos et al., 2012).

Fruit coating is a technique that aims to control the loss of mass through transpiration, reducing gas exchange, besides conserving the appearance, also contributing to the preservation of structural integrity and physical and morphological properties (Botrel et al., 2010). Fruit coating must be transparent, non-toxic, odorless, and flavorless (Souza et al., 2012). The biopolymers most used in the composition of edible films and coatings are proteins (gelatin, casein, ovalbumin, wheat gluten, zein, and myofibrillar proteins), polysaccharides (starch, pectin, cellulose, alginate, and carrageenan) and lipids (acetylated monoglycerides, stearic acid, waxes, and fatty acid esters) or a combination thereof (Falguera et al., 2011).

One of the biopolymers commonly used for the preparation of edible coating is starch, due to its low cost and the great abundance (Bessa et al., 2015). Starch has thermoplastic characteristics when a plasticizer is incorporated into the formulation, such as glycerol or sorbitol; however, protein-based coatings are more resistant and less permeable to water than coatings from polysaccharides (Belibi et al., 2013).

Given the above, this study aimed to evaluate the influence of coatings based on biopolymers on the maturation of cagaita during storage.

The fruits were collected in the germplasm bank of the Universidade Federal de Goiás (Federal University of
Goiás) - Campus of Samambaia, in Goiânia-GO, at geographic coordinates $16^{\circ} 35^{\prime} 12^{\prime \prime} \mathrm{S}, 49^{\circ} 21^{\prime} 14^{\prime \prime} \mathrm{W}$ and altitude of $730 \mathrm{~m}$.

One hundred fruits were harvested from ten different plants and subsequently selected according to their appearance due to the absence of lesions and visual uniformity (size and green color). After harvesting and selection, the fruits were washed with running water and neutral detergent, sanitized with chlorine in a concentration of $200 \mathrm{~g} \mathrm{~L}^{-1}$ for 15 minutes and exposed to drying at room temperature, where they were subjected to the treatment and storage.

The experiment was carried out in a $3 \times 4$ factorial scheme, with three treatments - fruits without coating, with polysaccharide coating and protein coating; 4 evaluation periods with an interval of 2 days, the fruits were stored in incubators for B.O.D. (biochemical oxygen demand), at $25^{\circ} \mathrm{C}$. A completely randomized design was used, and each treatment consisting of five fruit.

The coatings were prepared in two different formulations: the formulation of corn starch in the proportion of $4 \%$ of the total formulation, $92 \%$ of filtered water, $2 \%$ of glycerol, and $2 \%$ of unflavored gelatin. And the second formulation with $4 \%$ whey protein, $92 \%$ filtered water, $2 \%$ glycerol, and $2 \%$ unflavored gelatin. Gelatin helps in the texture and fixation of the coating, and glycerol acts as a plasticizer in both formulations. The solutions were solubilized and heated to $90{ }^{\circ} \mathrm{C}$ in a water bath and cooled to $25^{\circ} \mathrm{C}$. The fruits were immersed in the solutions for 5 minutes and exposed so that the coating could dry. After drying, the fruits were placed in the B.O.D., at a temperature of $25^{\circ} \mathrm{C}$.

The fruits were evaluated for ascorbic acid content, expressed in milligrams of ascorbic acid per 100 grams of sample (Strohecker and Henning, 1967). Mass loss was determined by weighing the fruits on a precision scale. Soluble solids (SS), $\mathrm{pH}$, and titratable acidity (TA) were determined according to the methodologies described by AOAC (2010).

The data were analyzed according to their homogeneity (by the Shapiro-Wilk test) and normality (by the Bartlet-test), then followed by the analysis of variance at $5 \%$ probability. The means were compared by the Tukey test. For quantitative data, linear and quadratic regression analysis was performed. The analyzes were performed with the software R (R Core Team, 2017).

There is the significance of the time factor in the present study $(\mathrm{p}>0.05)$. For titratable acidity, ascorbic acid, soluble solids, and $\mathrm{pH}$, there was no significant difference $(\mathrm{p}>0.05)$ between treatments (Table 1). About mass loss $(\%)$, there was a significant difference $(\mathrm{p}>$ 0.05 ) between treatments, with the treatment without coating, showing a loss of mass similar to the treatment with a protein coating and higher than the starch coating. 
The protein coating treatment did not differ statistically from any other treatment $(\mathrm{p}>0.05)$.

In this study, the treatment with starch coating promoted less loss of mass to the cagaita (Figure 1A). This is due to the interaction of the coating on the surface of the fruit, making it more resistant to water vapor exchanges. The ascorbic acid content showed no interaction between days and treatments (Figure 1B), and the results were, on average, $32.19 \mathrm{mg} \mathrm{g}^{-1}$. Fruits may have an increase or decrease in ascorbic acid content when stored; how the fruit will behave will depend on its physiology, on the stage of maturation and can range even from one plant to another. The decrease occurs due to the action of ascorbic acid oxidase, since its enzymatic activity has a higher action on ripe fruits than on green ones, as ripe fruits have greater availability of water and nutrients (Cardoso et al., 2011; Silva et al., 2008).

About the $\mathrm{pH}$ (Figure 1C), it was noted that it did not suffer significant reactions during the storage period, being on average 3.78 higher than the results found in other studies, between 2.22 and 3.09 for the ripe fruit, and 2.84 for green fruit (Silva et al., 2008, Camilo et al., 2014).

The content of soluble solids (Figure 1B) varied between 5 and $7^{\circ}$ Brix. According to studies by Silva et al. (2017), the fruits harvested with 10 and 37 DAA (days after anthesis) obtained 5.33 and $10.7^{\circ}$ Brix, respectively.
Cardoso et al. (2011) and Camilo et al. (2014) found for ripe fruit values between 5.20 and $9.1{ }^{\circ}$ Brix. The increase in the content of soluble solids during ripening is due to the conversion of complex sugars present in the fruit; in simpler sugars, this reaction is of great significance, making the fruits sweeter with development and ripening. After ripening, the senescence of the fruits and the reduction of soluble solids content occur, due to the use of the simplest sugars as an energy substrate (Chitarra and Chitarra, 1990; França et al., 2018), thus being the main indicator of ripeness of fruit.

Low interaction of the coatings with the fruit and its physical-chemical quality implies the need to evaluate other factors, such as the point of the harvest of the fruit, for example. Studies by Silva et al. (2017) indicate that the cagaita is a climacteric fruit, with a respiratory peak occurring before the ethylene peak, where the fruits can be harvested after 31 DAA. However, it is known that this point of harvest not yet standardized for the fruit can range from one season to another, which can influence the behavior after harvesting the fruit.

The results obtained in this study allow us to conclude that it is necessary to develop a methodology for determining the ideal harvest point for cagaita, and that among the coatings, under the conditions of this experiment, the one that showed the best result was the starch.

Table 1. Titratable Acidity (TA), Ascorbic Acid (AA), Soluble Solids (SS), pH and Mass Loss (ML) of cagaita fruits (Eugenia dysenterica DC.) submitted to the treatments (non-coating, protein coating, with whey protein, and starch coating, with corn starch), Urutaí - GO, 2018.

\begin{tabular}{lccccc}
\hline Treatment & ML $(\%)$ & TA $(\mathrm{g} / 100 \mathrm{~g})$ & $\mathrm{AA}(\mathrm{mg} / 100 \mathrm{~g})$ & $\mathrm{SS}\left({ }^{\circ}\right.$ Brix $)$ & $\mathrm{pH}$ \\
\hline Non-coating & $16.24 \mathrm{a}$ & $0.07^{\mathrm{a}}$ & $30.97 \mathrm{a}$ & $5.5 \mathrm{a}$ & $3.77 \mathrm{a}$ \\
Protein coating & $11.58 \mathrm{ab}$ & $0.06^{\mathrm{a}}$ & $32.44 \mathrm{a}$ & $5.6 \mathrm{a}$ & $3.79 \mathrm{a}$ \\
Starch coating & $10.17 \mathrm{~b}$ & $0.08^{\mathrm{a}}$ & $33.16 \mathrm{a}$ & $6.0 \mathrm{a}$ & $3.80 \mathrm{a}$ \\
Average & 12.66 & 0,07 & 32.19 & 5.7 & 3.78 \\
CV\% & 44.25 & 28.62 & 24.04 & 14.63 & 4.37 \\
p-value & 0.03 & 0.17 & 0.78 & 0.30 & 0.91 \\
\hline
\end{tabular}

${ }^{\mathrm{a}, \mathrm{b}}$ Means followed by the same letters in the column do not differ statistically by the Tukey test at $5 \%$ probability.

A

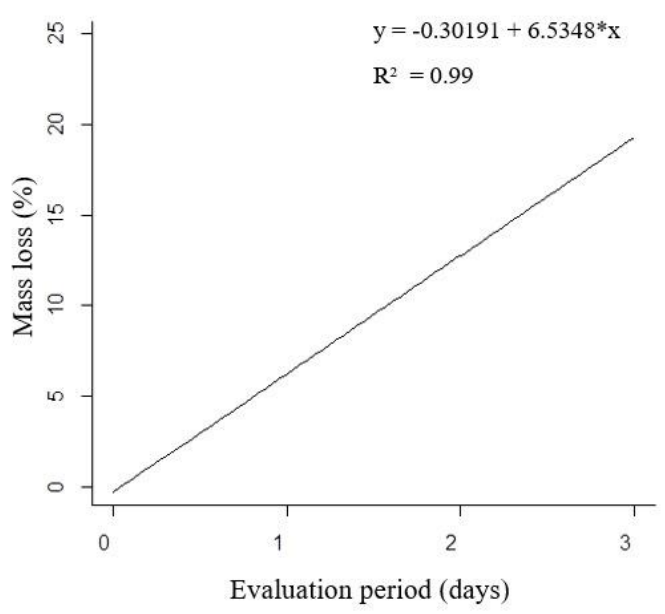

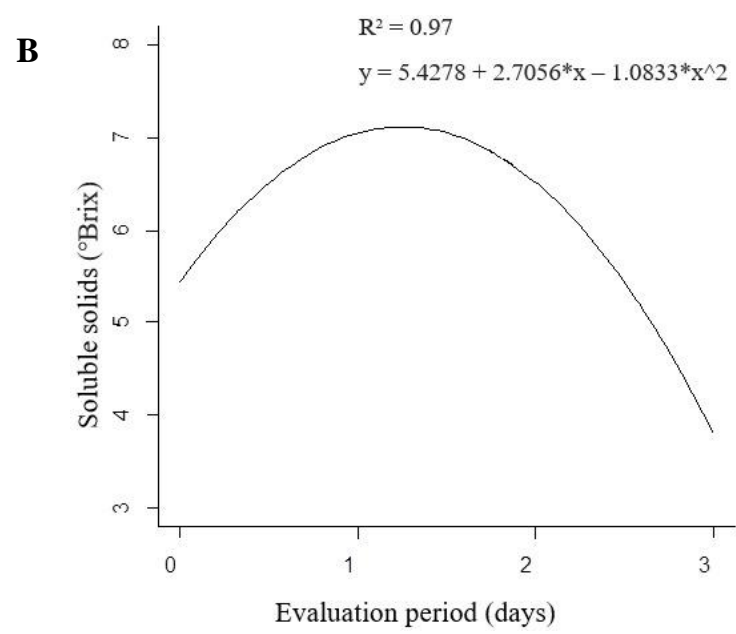



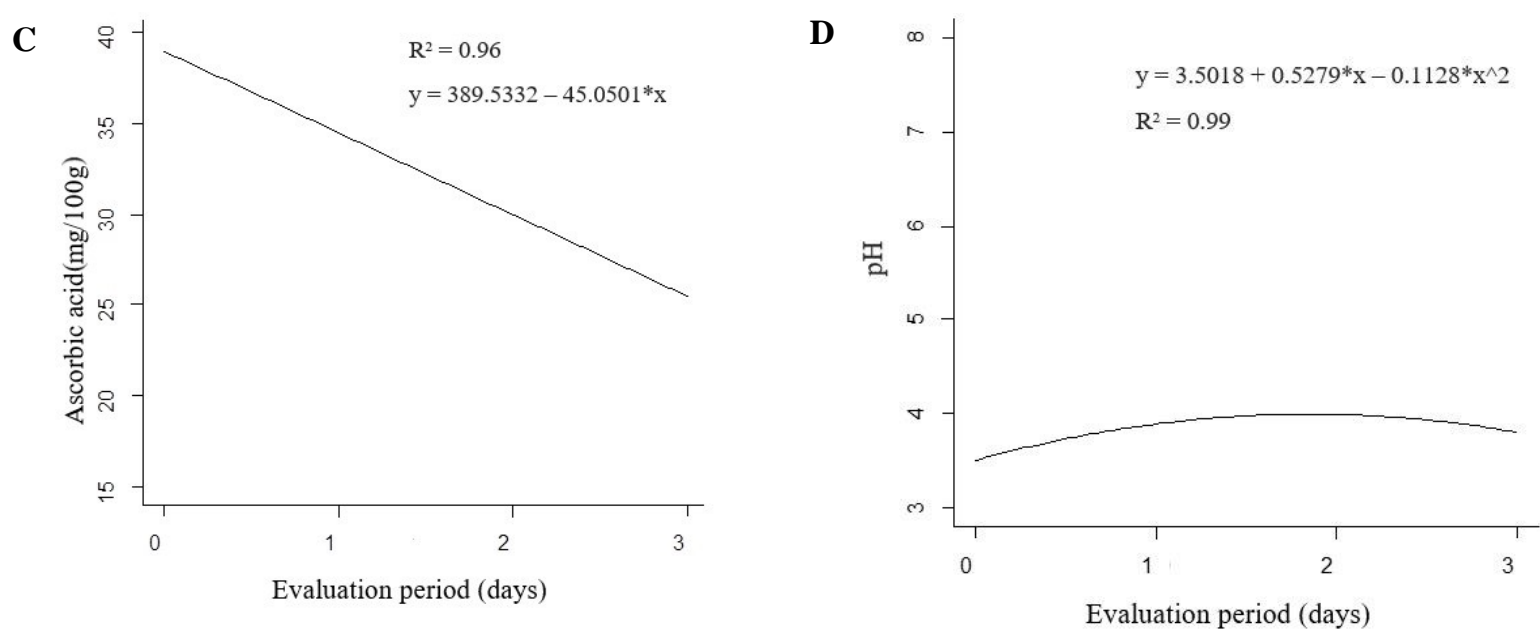

Figure 1. (A) Mass Loss (ML), (B) Soluble solids ( ${ }^{\circ}$ Brix), (C) Ascorbic acid (AA) $\mathrm{mg} \mathrm{g}^{-1}$, (D) $\mathrm{pH}$, of cagaita fruits (Eugenia dysenterica DC.), during storage.

\section{Bibliographic References}

Almeida Júnior, E.B.D., Chaves, L.J., Soares, T.N., 2014. Genetic characterization of a germplasm collection of cagaiteira, a native species of the cerrado. Bragantia, 73(3), 246-252.

AOAC. Association Official Analytical Chemistis, 2010. Official Methods of Analysis of AOAC International, 18th ed. AOAC International, Gaithersburg.

Belibi, P.C., Daou, T.J., Ndjaka, J.M.B., Michelin, L., Brendlé, J., Nsom, B., Durand, B., 2013. Tensile and water barrier properties of cassava starch composite films reinforced by synthetic zeolite and beidellite. Journal of Food Engineering, 115(3), 339-346.

Bessa, R.A., Oliveira, L.H., Arraes, D.D., Batista, E.S., Nogueira, D.H., Silva, M.S., Ramos P.H., Loiola, A.R., 2015. Filmes de amido e de amido/zeólita aplicados no recobrimento e conservação de goiaba (Psidium guajava). Revista Virtual de Química, 7(6), 2190-2201.

Botrel, D.A., Soares, N.F.F., Camilloto, G.P., Fernandes, R.V.B., 2010. Revestimento ativo de amido na conservação pós-colheita de pera Williams minimamente processada. Ciência Rural, 40(8), 1814-1820.

Camilo, Y.M.V., Souza, E.R.B., Vera, R., Naves, R.V., 2014. Caracterização de frutos e seleção de progênies de cagaiteiras (Eugenia dysenterica DC.). Científica, 42(1), 1-10.

Cardoso, L.M., Martino, H.S.D., Moreira, A.V.B., Ribeiro, S.M.R., Pinheiro-Sant'Ana, H.M., 2011. Cagaita (Eugenia dysenterica DC.) of the Cerrado of Minas Gerais, Brazil: physical and Chemical characterization, carotenoids and vitamins. Food Research International, 44(7), 2151-2154.

Chitarra, M.I.F., Chitarra, A.B., 1990. Pós-colheita de frutos e hortaliças: fisiologia e manuseio. ESAL/FAEPE, Lavras.

Chitarra, M.I.F., Chitarra, A.B., 2005. Pós-colheita de frutas e hortaliças: fisiologia e manuseio, segunda ed. UFLA, Lavras.

Falguera, V., Quintero, J.P, Jiménez, A., Muñoz, J.A, Ibarz, A., 2011. Filmes e revestimentos comestíveis: Estruturas, funções ativas e tendências em seu uso. Tendências em Ciência e Tecnologia de Alimentos, 22(6), 292-303.

França, D.L.B., Braga, G.C., Laureth, J.C.U., Dranski, J.A.L., Moura, C.A., 2018. Physiological response, antioxidant enzyme activities and conservation of banana treated with ethanol vapor. Journal of Food Science and Technology, 56(1), 208-216.

R Core Team, 2017. R: A language and environment for statistical computing. R Foundation for Statistical Computing, Vienna, Austria. http://www.R-project.org/ (acessado 16 de dezembro de 2018).

Santos, P.R.G., Cardoso, L.D.M., Bedetti, S.D.F., Hamacek, F.R., Moreira, A.V.B., Martino, H.S.D., Pinheiro-Sant'Ana, H.M., 2012. Cagaita (Eugenia dysenterica DC.) jelly: development, microbiological, sensory, chemical characterization, and stability study. Revista do Instituto Adolfo Lutz (Impresso), 71(2), 281-290.

Silva, M.M.M., Silva, E.P., Silva, F.A., Ogando, F.I.B., Aguiar, C.L., Damiani, C., 2017. Physiological development of cagaita (Eugenia dysenterica). Food Chemistry, 217, 74-80.

Silva, M.R., Santos Júnior, R.T.O., Ferreira, C.C.C., 2008. Estabilidade da vitamina $\mathrm{C}$ em cagaita in natura e durante a estocagem da polpa e refresco. Pesquisa Agropecuária Tropical, 38(1), 53-58.

Silva, S., Tassara, H., 2003. Frutas no Brasil, quinta ed. Editare, São Paulo.

Souza, A.C., Benze, R.F.E.S., Ferrão, E.S., Ditchfield, C., Coelho, A.C.V., Tadini, C.C., 2012. Cassava starch biodegradable films: Influence of glycerol and clay nanoparticles content on tensile and barrier properties and glass transition temperature. LWT - Food Science and Technology, 46(1), 110-117.

Strohecker, R.L., Henning, H.M., 1967. Analisis de vitaminas: métodos comprobados. Madrid: Paz Montalvo.

Terán-Ortiz, G.P., Silva, M.G., Lima, H.C., Paciulli, S.O.D., Silva, V.A., 2013. Avaliação pós colheita de cagaita (Eugenia Dysenterica). Magistra, 25, 1-6. 